\title{
Geochemical characterization of supraglacial debris via in situ and optical remote sensing methods: a case study in Khumbu Himalaya, Nepal
}

\author{
K. A. Casey ${ }^{1, *}$, A. Kääb ${ }^{1}$, and D. I. Benn ${ }^{2,3}$ \\ ${ }^{1}$ Department of Geosciences, University of Oslo, P.O. Box 1047 Blindern, 0316 Oslo, Norway \\ ${ }^{2}$ Department of Geography, University of St. Andrews, St. Andrews, UK \\ ${ }^{3}$ The University Centre in Svalbard (UNIS), P.O. Box 156, 9171 Longyearbyen, Norway \\ *now at: NASA Goddard Space Flight Center, Cryospheric Sciences Laboratory, Greenbelt, MD 20771, USA \\ Correspondence to: K. A. Casey (kimberly.a.casey@ nasa.gov)
}

Received: 28 November 2010 - Published in The Cryosphere Discuss.: 7 February 2011

Revised: 22 July 2011 - Accepted: 13 December 2011 - Published: 19 January 2012

\begin{abstract}
Surface glacier debris samples and field spectra were collected from the ablation zones of Nepal Himalaya Ngozumpa and Khumbu glaciers in November and December 2009. Geochemical and mineral compositions of supraglacial debris were determined by X-ray diffraction and $\mathrm{X}$-ray fluorescence spectroscopy. This composition data was used as ground truth in evaluating field spectra and satellite supraglacial debris composition and mapping methods. Satellite remote sensing methods for characterizing glacial surface debris include visible to thermal infrared hyper- and multispectral reflectance and emission signature identification, semi-quantitative mineral abundance indicies and spectral image composites. Satellite derived supraglacial debris mineral maps displayed the predominance of layered silicates, hydroxyl-bearing and calcite minerals on Khumbu Himalayan glaciers. Supraglacial mineral maps compared with satellite thermal data revealed correlations between glacier surface composition and glacier surface temperature. Glacier velocity displacement fields and shortwave, thermal infrared false color composites indicated the magnitude of mass flux at glacier confluences. The supraglacial debris mapping methods presented in this study can be used on a broader scale to improve, supplement and potentially reduce errors associated with glacier debris radiative property, composition, areal extent and mass flux quantifications.
\end{abstract}

\section{Context}

Many of the world's glaciers have moderate to significant surface debris. Supraglacial debris is derived from either local rock and ice fall or from atmospheric deposition of particulates. Inspection of debris composition can reveal these distinct geologic source contributions. Dust layers studied at the surface (e.g. Adhikary et al., 2000) or in ice cores (e.g. Thompson et al., 2000) can indicate climate conditions such as temperature and aridity. Local geologic sources, such as accumulation zone geologic compositions which reemerge supraglacially in the ablation zone, signal the magnitude and pathway of englacial transport. Debris mantle patterns and geologic assemblages indicate slope processes (i.e. rock or ice falls) (Benn and Evans, 2010), glacier flow regimes (i.e. continuous, pulsed or of surge type) and the kinematic history of a debris covered glacier.

While spaceborne remote sensing of 'clean' bare glacier ice extent can be done quite successfully (Hall et al., 1988), even on a semi-automated basis (Paul et al., 2002), strategies for supraglacial debris satellite mapping remain in development (e.g. Bhambri et al., 2011). Spaceborne glacier debris areal extent mapping methods use thermal, geomorphometric or recently synthetic aperture radar approaches (e.g. see Lougeay, 1974; Bishop et al., 1999; Bolch et al., 2007; Shukla et al., 2010; Atwood et al., 2010; Strozzi et al., 2010). Repeat satellite images can be used to estimate debris covered glacier surface velocity and theoretical surface particulate flow (e.g. Kääb, 2005; Scherler et al., 2008). 
In addition to glacier extent and kinetic studies, Wessels et al. (2002) used ASTER data to analyze spectral variability of supraglacial lakes in the Everest region; Kääb (2005) utilized false color ASTER band composites to indicate debris patterns and indication of flow regimes at Hispar glacier in the Karakorum, Pakistan and Unteraar glacier in the Swiss Alps; Suzuki et al. (2007) mapped thermal resistance of debris covered glaciers in the Lunana and Khumbu Himalayas; and Mihalcea et al. (2008) utilized ASTER data to map glacier debris spatial distribution and thickness. A summary of spaceborne glacier mapping challenges and recommendations for glacier parameter analysis is offered by Racoviteanu et al. (2010).

Spaceborne remote sensing of glacier debris towards geologic composition has not been investigated. We demonstrate that supraglacial composition can be mapped via spectral satellite data and is relevant to many glaciologic variables, including radiative absorption, ablation, generation of supraglacial melt as well as englacial and supraglacial mass flux. Further, these supraglacial debris composition impacts are applicable to glaciologic understanding at regional and global scales.

\section{Background}

\subsection{Sensors}

Earth observing satellite technology has advanced greatly in recent decades, offering rich spatial, temporal and spectral imaging of Earth's glaciers. Intended particularly for spectral signature studies (Abrams, 2000), the ASTER instrument measures 14 optical bands at spatial resolutions from 15 to 90 m. Specifically, ASTER measures three bands in the visible and near infrared (VNIR, 0.4-0.9 $\mu \mathrm{m})$ at $15 \mathrm{~m}$ spatial resolution, six shortwave infrared bands (SWIR, 1.0-2.5 $\mu \mathrm{m}$ ) at $30 \mathrm{~m}$ spatial resolution and five thermal infrared bands (TIR, $3.0-12 \mu \mathrm{m})$ at $90 \mathrm{~m}$ spatial resolution. Unfortunately, SWIR detectors failed in April 2008, therefore SWIR from 2008 to present is unavailable. However, ASTER VNIR and TIR bands continue to perform well at the date of publication, and SWIR data from 2000 to 2008 is usable. Landsat 7's Enhanced Thematic Mapper Plus (ETM+) provides 16-day temporal resolution with eight spectral bands: one panchromatic (pan) band at $15 \mathrm{~m}$ resolution, six VNIR-SWIR bands at $30 \mathrm{~m}$ resolution, and one TIR band at $60 \mathrm{~m}$ resolution. Additionally, Landsat 5 TM, with similar spectral (7 VNIRTIR bands, no pan) and spatial (30 m VNIR-SWIR, $120 \mathrm{~m}$ TIR) resolution, continues to acquire data. Further details on ASTER and Landsat sensors, including ETM+ scan line correction can be found in: Watanabe et al. (2011), Tucker et al. (2004) and Storey et al. (2005).

Part of a technological demonstration and validation mission, NASA's EO-1 satellite was launched in 2000 and carries two pushbroom sensors: Hyperion and Advanced Land
Imager (ALI). Hyperion uses a VNIR and a SWIR spectrometer to acquire 242 spectral bands from 0.4 to $2.5 \mu \mathrm{m}$ (in $10 \mathrm{~nm}$ nominal increments) at $30 \mathrm{~m}$ spatial resolution. Of the 242 spectral bands, only 220 are calibrated due to low response of detectors in non-calibrated bands. Approximately 24 bands measure at the same wavelength between the VNIR and SWIR spectrometers. Thus, there are 196 distinct spectral bands - VNIR bands 8 through 57, and SWIR bands 77 through 224. Similar in spectral resolution to the Landsat series, ALI offers one pan band and 9 visible to shortwave infrared bands. Compared to Landsat TM and ETM+, ALI offers improved VNIR to SWIR spectral resolution at the same spatial resolution $(30 \mathrm{~m})$, and improved pan band spatial resolution (10 m vs. ETM + pan $15 \mathrm{~m})$. However, ALI offers no TIR spectral data. Although EO-1 was only planned to run for 2-yr, operation has continued successfully and EO1 is now managed by the United States Geological Survey (USGS) (all Hyperion and ALI instrument data after Beck, 2003). Figure 1 provides a visual summary of spectral coverage of the different instruments, including MODIS which can be used to monitor larger glaciers.

\subsection{Lithologic remote sensing}

Pioneering laboratory and field based spectroscopy investigations toward deriving mineral and chemical composition were conducted by McClure (1957), Lyon (1965), Hunt and Salisbury (1970) and Clark and Lucey (1984) focusing strictly on ice/rock mixtures. These and other related studies determined that dominant anions, cations, trace constituents and crystal field structures strongly influence reflectance and emission spectra and can be used to resolve geochemical composition. Satellite spectral derivation of mineral and chemical constituents has progressed over the past several decades (e.g. Vincent and Thomson, 1972; Goetz and Rowan, 1981; Fu et al., 2007). Rowan et al. (1986); Rowan and Mars (2003) demonstrated that transition metal enrichment can be detected via use of VNIR. Hydroxide, sulfate and carbonate minerals can be analyzed using SWIR (Kruse, 1988; Rowan and Mars, 2003; Ninomiya et al., 2005). Silicate, carbonate, oxide, phosphate, and sulfate minerals have been measured via TIR spectral studies (e.g. Gillespie et al., 1984; Hook et al., 1992; Ninomiya et al., 2005).

To validate remotely sensed geologic composition, analytical geochemical techniques are often used. X-ray diffraction (XRD) identifies mineralogy, while X-ray fluorescence spectroscopy (XRF) measures oxide compound weight percent (e.g. $\mathrm{SiO}_{2}, \mathrm{Al}_{2} \mathrm{O}_{3}, \mathrm{Fe}_{2} \mathrm{O}_{3}, \mathrm{CaO}$ ) and trace element concentration (e.g. V, Co, Zn, Pb). The XRD derived mineralogy and XRF measured geochemical composition provide an independent assessment of debris composition to compare with spectrally determined measurements.

In this study, we evaluate full optical spectrum VNIR-TIR spectral techniques toward measuring mineralogy and geochemical composition of surface glacier debris. Multi- and 


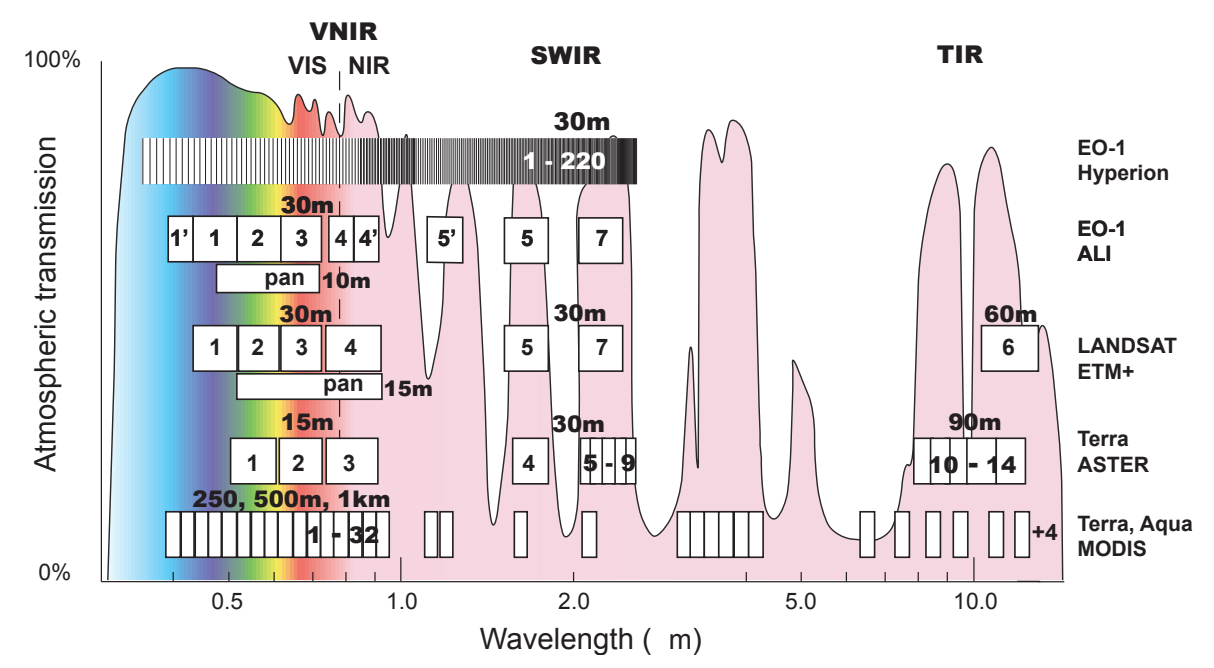

Fig. 1. Spectral and spatial resolution of Hyperion, ALI, Landsat ETM+, ASTER and MODIS sensors shown with respect to visible to thermal infrared atmospheric transmission (revised after (Kääb, 2005)).

hyperspectral data of the Khumbu Himalayas, acquired from a variety of sensors are used. Ngozumpa and Khumbu glacier field collected spectra and XRD and XRF debris sample mineralogy and geochemical composition serve as ground truth. To the authors' knowledge, the is the first study to explore full optical spectrum satellite derived qualitative and quantitative characterization of supraglacial debris.

\section{Study area}

The Hindu Kush-Himalayas constitute one of the largest areas of land-based ice apart from the Greenland and Antarctic ice sheets. Debris covered glacier area in the Hindu Kush-Himalaya is sizeable (e.g. discussed in Scherler et al., 2011), constituting roughly $14 \%$ of Hindu Kush-Himalaya ice (based on an unpublished Hindu Kush-Himalaya satellite data glacier inventory estimate by the 2 nd author). The extreme topography of the Khumbu Himalaya region results in frequent rock falls and ice avalanches at regional glaciers. These rock falls and ice avalanches contribute to the heavy debris cover, high supraglacial activity, sediment transport, deposition and glacial erosion on both Ngozumpa and Khumbu glaciers (Benn and Owen, 2002).

Ngozumpa glacier is the longest glacier in Nepal - approximately $25 \mathrm{~km}$ in length (Benn et al., 2001); Khumbu glacier is $17 \mathrm{~km}$ in length (Hambrey et al., 2008) (Fig. 2). Ngozumpa and Khumbu glacier surface debris consists primarily of leucogranite, greenschist and sillimanite-gneiss sands, gravels, rocks and boulders, with primary mineral components including quartz, feldspars, micas, and carbonates (Carosi et al., 1999; Searle et al., 2003). Extensive debris cover on both glacier tongues increases in depth down glacier and insulates the underlying ice (Kadota et al., 2000). Both glaciers are typified by considerable supraglacial relief, with the height difference between peaks and troughs estimated at 20-50 m (observed during 2009 field work and reported in Benn and Owen, 2002).

Downwasting or thinning of Khumbu Himalayan glaciers has been observed over the past several decades (Bolch et al., 2008a, 2011; Nuimura et al., 2011). In addition to downwasting, backwasting - the ablation which occurs on exposed ice faces in debris covered areas - is another primary melt mechanism active on Khumbu Himalayan glaciers. Backwasting was found to account for up to $20 \%$ of the total ablation of debris covered area by Nakawo et al. (1999). Backwasting related topographic inversion processes (detailed in Benn and Evans, 2010) occur on these debris-mantled glaciers, yielding complex debris assemblages and numerous supraglacial melt ponds (Wessels et al., 2002).

\section{Data collection and methods}

\subsection{In situ data collection}

Over 3360 field spectra were collected on Ngozumpa and Khumbu glaciers in November and December 2009. Specifically, more than 1800 spectra were collected in the middle ablation area of the Ngozumpa glacier (approx. 47354790 m a.s.l) from 26-29 November 2009, and more than 1560 spectra were collected in the upper ablation area of the Khumbu glacier (approx. 5100-5285 m a.s.1.) from 4-6 December 2009. The locations of the data collection sites are detailed in Fig. 2 and Table 1.

Surface radiance was measured with an Analytical Spectral Devices (ASD) FieldSpec Pro (Analytical Spectral Devices, 2002), collecting nadir "raw mode" surface radiance on clear sky days within two hours of local solar noon (10:00 a.m.-02:00 p.m., LT). An $18^{\circ}$ foreoptic was used with 
Table 1. Summary of in situ sample attributes, including location, elevation, as well as data collection date, sample type and sample ID. The locations of the field measurement sites are mapped in Fig. 2 and sample ID's are also referred to in Table 3.

\begin{tabular}{|c|c|c|c|c|}
\hline Location & Date & Latitude / Longitude & Elevation (m a.s.1.) & $\begin{array}{l}\text { Spectral signature class, } \\
\text { (corresponding sample ID) }\end{array}$ \\
\hline Upper Ngozumpa (UN) & 27 November 2009 & $27.9568^{\circ} \mathrm{N} 86.6980^{\circ} \mathrm{E}$ & 4760 & snow, rock, gravel, sand, mud $(1 \mathrm{~N}-6 \mathrm{~N})$ \\
\hline Lower Ngozumpa (LN) & 26 November 2009 & $27.9511^{\circ} \mathrm{N} 86.7020^{\circ} \mathrm{E}$ & 4790 & snow, boulders, gravel, soil \\
\hline Upper Khumbu (UK) & 6 December 2009 & $27.9998^{\circ} \mathrm{N} 86.8511^{\circ} \mathrm{E}$ & 5280 & ice, snow, gravel (19K-22K) \\
\hline Mid-Khumbu (MK) & 5 December 2009 & $27.9874^{\circ} \mathrm{N} 86.8405^{\circ} \mathrm{E}$ & 5180 & ice, snow, rock, sand $(14 \mathrm{~K}-18 \mathrm{~K})$ \\
\hline
\end{tabular}

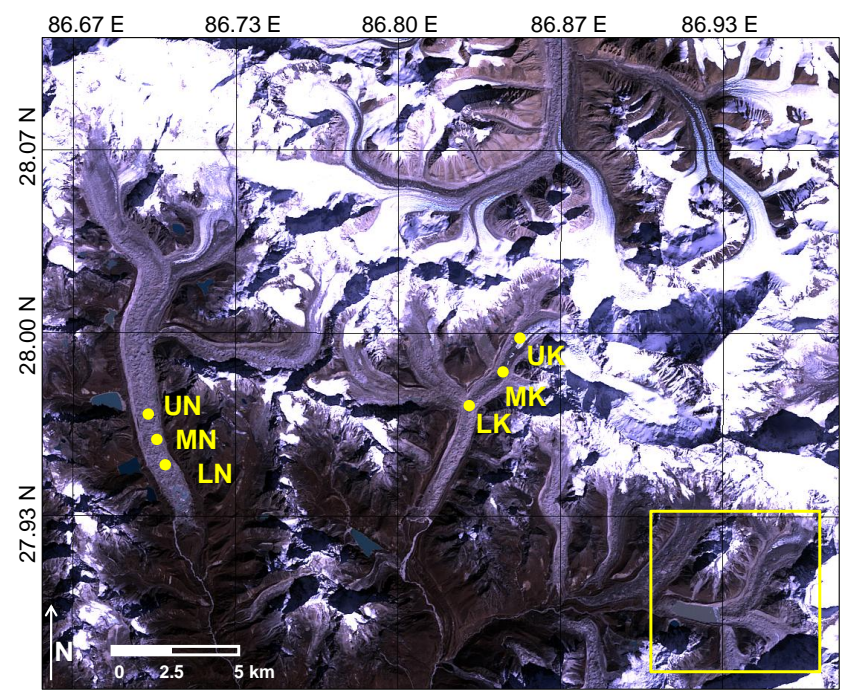

Fig. 2. Landsat TM (31 October 2009) true color composite of the Khumbu Himalaya study area. Ngozumpa glacier (left) and Khumbu glacier (right) in situ measurement locations are labeled as detailed in Table 1. The approximate area presented in the Hyperion Imja and Lhotse Shar glacier analysis is highlighted with a yellow box in the lower right hand corner.

the spectrometer to target distances ranging from $10 \mathrm{~cm}$ to $1 \mathrm{~m}$ (relating to approximately $3 \mathrm{~cm}^{2}$ to $30 \mathrm{~cm}^{2}$ surface resolution). A Spectralon calibration panel served as the reference material to glacier surface measurements.

Spectral targets included snow, ice, variations of dust and debris, and partially vegetated glacier surfaces. For each targeted glacier surface material, 20-30 measurements were acquired. In situ sample sites representative of both pure (e.g. bare ice, granitic debris) and mixed (e.g. ice with schistic pebbles) targets were selected to maximize thematic spectral acquisitions while safely maneuvering on the active glacier in the short solar noon temporal window. Geographic location and glacier surface temperatures were recorded for each set of spectral class measurements.
In conjunction with spectral measurements, 19 snow and ice samples (in acid prepared $500 \mathrm{ml}$ low density polypropylene Nalgene bottles), and 22 supraglacial debris samples (in clean polyethylene bags, obtaining approximately 100 grams of material per sample) were collected. All in situ samples were taken in duplicate and double polyethylene bagged.

\subsection{Analysis of in situ data}

Post collection analysis of field spectra involved converting instrumental digital numbers to calibrated surface radiance to spectral reflectance (after Nicodemus et al., 1977). Measured target reflectance was divided by Spectralon calibrated reference surface reflectance, and multiplied by both calibration panel offsets and the user defined reflectance scale for each wavelength $(0.35-2.5 \mu \mathrm{m})$. Due to FieldSpec Pro instrument variability from the $57 \mathrm{VNIR/SWIR}$ individual optical fiber responses (MacArthur et al., 2007), signal-to-noise ratios, three detectors (Analytical Spectral Devices, 2002), as well as for comparison of field spectra with satellite spectral data, repeat field spectra over each target were averaged to form field spectral reflectance class signatures (here after referred to as spectral signatures).

We measured the mineralogy, oxide and elemental composition of Ngozumpa and Khumbu glacier debris samples using powder XRD and XRF at the University of Oslo, Department of Geosciences. Glacier debris samples were prepared for XRD and XRF analysis by drying (2 days at $80^{\circ} \mathrm{C}$ ) and crushing to a fine powder (less than $125 \mu \mathrm{m}$ particle size) via a vibratory ringmill. Powder XRD was conducted via use of a Philips XPERT diffractometer (manufactured by PANalytical B.V., Almelo) with samples analyzed in FORCE Bulk Mode measuring from $2^{\circ}$ to $65^{\circ} 2 \Theta$. Mineralogy was derived via use of PANalytical's $X^{\prime}$ pert Highscore software, with semi-quantitative peak area and weight factor estimates of percent composition were calculated after Moore (1997). For XRF, ten grams of oven dried fine powder was prepared into sample tablets and measured on a Philips PW2400 XRF spectrometer run via SuperQ Version 3 software in TRACES $7 \mathrm{~B}$ mode. The following oxide compounds and trace elements were measured: $\mathrm{SiO}_{2}, \mathrm{Al}_{2} \mathrm{O}_{3}, \mathrm{Fe}_{2} \mathrm{O}_{3}, \mathrm{MnO}, \mathrm{MgO}$, 
Table 2. A listing of the satellite products and scene dates used for the optical remote sensing methods evaluated in this study.

\begin{tabular}{lll}
\hline Comparison method & Sensor, data product & Date(s) of scene(s), further details \\
\hline $\begin{array}{l}\text { Satellite reflectance } \\
\text { multispectral } \\
\text { hyperspectral }\end{array}$ & ASTER, AST_07XT & 29 November 2005, surface reflectance \\
& Hyperion, L1GST & 13 May 2002, 4 October 2010, top of atmosphere reflectance \\
True and false color composites & ALI, L1T & 4 October 2010, 10 m pan enhanced true color \\
& ASTER, L1B & 29 November 2005, SWIR/TIR false color \\
& Landsat TM, L1T & 31 October 2009, true color \\
& Landsat ETM+, L1G & 24 January 2003, SWIR/TIR false color \\
& Hyperion, L1T & 13 May 2002, true color, SWIR false color \\
& & \\
Mineralogic mapping: & ASTER, L1B & 29 November 2005, at-sensor radiance \\
SWIR/TIR indices & ASTER, AST_05 & 29 November 2005, emissivity \\
SiO 2 weight percent & Landsat TM, L1T & 31 October 2009, at-sensor radiance converted to LST \\
& Landsat ETM+, L1G & 30 October 2000, 4 October 2002, 15 m pan \\
Land surface temperature & Landsat TM, L1T & 5 November 2005, 31 October 2009, 30 m near infrared \\
\hline
\end{tabular}

$\mathrm{CaO}, \mathrm{Na}_{2} \mathrm{O}, \mathrm{K}_{2} \mathrm{O}, \mathrm{TiO}_{2}, \mathrm{P}_{2} \mathrm{O}_{5}$, and $\mathrm{V}, \mathrm{Co}, \mathrm{Zn}, \mathrm{Rb}, \mathrm{Pb}, \mathrm{Sr}, \mathrm{Y}$, $\mathrm{Zr}, \mathrm{Nb}, \mathrm{Th}, \mathrm{U}, \mathrm{Ba}, \mathrm{S}$. Accuracy of XRF results is $98 \%$.

\subsection{Optical satellite data acquisition and processing}

Satellite remote sensing data were acquired with the closest temporal and seasonal (post-monsoon dry season) correlation to in situ collected data, avoiding instrument anomalies (i.e. Landsat ETM+ scan line correction, ASTER SWIR band failures). The specific satellite data products used include: ASTER L1B at-sensor radiance, ASTER AST_07XT surface reflectance, ASTER AST_05 surface emissivity, Landsat TM Level $1 \mathrm{~T}$ and ETM + Level $1 \mathrm{G}$ at-sensor radiance, and Hyperion Level 1GST at-sensor radiance. Satellite data acquisition dates, data products and methods used to investigate Khumbu Himalayan glacier debris cover are listed in Table 2 and further described in the following sections.

\subsubsection{Mineral mapping}

The rich SWIR and TIR spectral resolution provided by ASTER allow for qualitative and quantitative approaches to mapping surface mineralogy. ASTER is used in this study, however, comparable spectral bands (e.g. see Fig. 1) can also be used to map supraglacial debris mineralogy. Three mineral mapping methods are presented: SWIR indices, TIR indices and TIR emissivity silica weight percent.

\section{SWIR indices}

SWIR mineral indices use wavelength dependant spectral absorption features to estimate mineral abundance. Several mineral indices are available and were evaluated (e.g. Vincent and Thomson, 1972; Ninomiya, 2003, 2004; Ninomiya et al., 2005). Based on the dominant minerals in the Khumbu Himalaya study area, the following SWIR mineral indices were chosen for evaluation: layered silicate (LS) (Eq. 1), calcite (CA) (Eq. 2), hydroxyl-bearing (OH) (Eq. 3) and alunite (AL) (Eq. 4).

$$
\begin{aligned}
& \mathrm{LS}=\frac{(\mathrm{AST} 4 \times \mathrm{AST})}{(\mathrm{AST} 5 \times \mathrm{AST})} \\
& \mathrm{CA}=\frac{\left(\mathrm{AST} 6 \times \mathrm{AST}^{2}\right)}{\left(\mathrm{AST}^{2}\right)} \\
& \mathrm{OH}=\frac{\left(\mathrm{AST} 4 \times \mathrm{AST}^{2}\right)}{\left(\mathrm{AST}^{2}\right)} \\
& \mathrm{AL}=\frac{\left(\mathrm{AST}^{2}\right)}{\left(\mathrm{AST} 5 \times \mathrm{AST}^{2}\right)}
\end{aligned}
$$

where AST $n$ corresponds to ASTER spectral band number $n$.

ASTER L1B at-sensor radiance data is used for mineral index estimations. The different indices are designed to extract absorption features key to the targeted mineral. For example, the LS and CA SWIR indices target bands that measure hydroxyl $(2.2 \mu \mathrm{m})$ and carbonate $(2.35 \mu \mathrm{m})$ absorption features, respectively. At-sensor radiance band ratios reduce atmospheric and topographic influences, including illumination variability (Abrams et al., 1983; Mather, 1987; Kääb, 2005), highlight information not evident in single band or 
three-band true or false color composite images, and provide a quantitative estimate of mineral abundances.

\section{TIR indices}

Thermal at-sensor radiance indices offer the first strictly thermal spectrum based technique presented in this study. Although the thermal portion of the spectrum is described as the most important region of the spectrum for differentiating geology of terrestrial materials (Gupta, 2003), TIR satellite spatial resolution is considerably lower than VNIR or SWIR (i.e. ASTER VNIR $15 \mathrm{~m}$, SWIR $30 \mathrm{~m}$, TIR $90 \mathrm{~m}$ spatial resolution). Nevertheless, TIR offers unique potential to target the abundance of carbonate, quartz and silicate mineral groups. TIR based band ratios to estimate carbonate, quartz and silica containing lithology are presented in Eqs. (5-7) (after Ninomiya et al., 2005).

$\mathrm{CI}=\frac{(\mathrm{AST} 13)}{(\mathrm{AST} 14)}$

$\mathrm{QI}=\frac{\left(\mathrm{AST} 11^{2}\right)}{(\mathrm{AST} 10 \times \mathrm{AST} 12)}$

$\mathrm{MI}=\frac{\left(\mathrm{AST} 12 \times \mathrm{AST}_{14}^{3}\right)}{\left(\mathrm{AST} 13^{4}\right)}$

where AST $n$ corresponds to ASTER spectral band number $n$.

The carbonate index (CI) is utilized to detect the primary carbonate minerals calcite and dolomite - with high values of CI indicating presence of these minerals (absorption features at $11.4 \mu \mathrm{m}$ for calcite, $11.2 \mu \mathrm{m}$ for dolomite). Pure carbonate will provide a high CI value in conjunction with and low QI and MI values. The quartz index (QI) not only is indicative of quartz, but also low QI values signal presence of potassium feldspar and gypsum. The mafic index (MI) correlates with silicate content, and is also sensitive to carbonate content in rocks. A simple silicate index ratio of band 12 to band 13 can be used - but for the differentiation from carbonates, Eq. (7) is used. A MI value greater than 0.90 corresponds to mafic rocks, while a MI value greater than 0.92 corresponds to ultramafic rocks (Ninomiya et al., 2005). To note, Ninomiya et al. (2005) concluded the stability of TIR mineral indices irrespective of surface temperature, elevation and atmospheric condition.

\section{TIR silica abundance}

Another technique to extract the dense geologic information available in the thermal bands is emissivity derived silica abundance mapping (Hook et al., 1992; Miyatake, 2000) Eq. (8) (after Watanabe and Matsuo, 2003). Using the ASTER Surface Emissivity AST_05 product, silica weight percent abundance is calculated by targeting characteristic silicate emission features in TIR.
$\mathrm{SiO}_{2}=56.20-271.09 \times \log \left[\frac{(\mathrm{AST} 10+\mathrm{AST} 11+\mathrm{AST} 12)}{(3 \times \mathrm{AST} 13)}\right](8)$

where ASTn corresponds to ASTER AST_05 surface emissivity product band number $n$.

\subsubsection{Shortwave and thermal infrared false color composites}

False color image composites can highlight geologic differences not evident in true color images. Landsat and ASTER offer SWIR and TIR bands that can be used to inspect supraglacial debris (Kääb, 2005). Landsat ETM+ thermal band $6(11 \mu \mathrm{m})$ allows for spectral emission analysis of carbonate and silicate content in supraglacial debris, and Landsat ETM + SWIR bands 5 and 7 (1.65 and $2.2 \mu \mathrm{m}$, respectively) indicate hydroxyl content, common to clays and hydrated silicates.

\subsubsection{Hyperspectral reflectance}

Although Hyperion coverage of the in situ measurement sites does not exist at the time of publication, Hyperion data of nearby Lhotse Shar and Imja glaciers from 13 May 2002 exists and was analyzed for supraglacial debris characteristics. Hyperion Level 1 GST terrain-corrected digital numbers were converted to at-sensor radiance using sensor- and band-specific calibration settings (e.g. gain, offset, solar irradiance). At-sensor, top-of-atmosphere (TOA) planetary reflectance was calculated for each band after Markham and Barker (1986) and atmospheric gas interferences from water vapor, oxygen and carbon dioxide were removed. To note, several commercial software programs are available to estimate surface reflectance (primarily addressing atmospheric correction) (e.g. see Dadon et al., 2010; Wang et al., 2010). Commercial software was not available to the authors, thus, Hyperion TOA reflectance is presented with removal of known atmospheric absorption interference features.

\subsubsection{Complementary supraglacial debrismapping methods}

Optical remote sensing glacier debris spatial analysis techniques complementary to the supraglacial debris composition mapping methods include calculation of glacier surface temperature and velocity. Land surface temperature (LST) over glaciers can be derived from thermal band spectral satellite data. For this study, we calculated LST from Landsat ETM+ and TM thermal band spectral data (method after Barsi et al., 2005; explained in Hall et al., 2008) using a dirty ice emissivity of 0.96 after (Qunzhu et al., 1985). Glacier surface velocity, or horizontal surface displacements were derived using normalized cross-correlation repeat Landsat TM near-infrared band and repeat ETM+ pan data (methods detailed in Kääb and Vollmer, 2000; Debella-Gilo and Kääb, 2011). With the assumption that the calculated velocity field 
is constant over time, relative surface ages were estimated from horizontal surface displacement velocity field interpolation (Haug et al., 2010). Streamlines then give theoretical transport time of glacier mass.

\section{Results}

\subsection{In situ spectra and debris geochemical composition}

Several snow and ice spectral signatures (clean snow, fine particulate covered snow, granitic gravel on snow, bare ice, ice with schistic pebbles, and full schistic debris cover) collected in the upper Khumbu glacier are presented in Fig. 3. As glacier surface dust and debris cover increases, VNIR reflectance decreases, as visualized by the "granitic gravel on snow" compared with "clean snow" and "schistic pebbles on ice" compared with "bare ice" spectral signatures in Fig. 3. Both fine particulates and granitic gravel reduce VNIR reflectance of clean snow, with fine particulates displaying an absorption feature minima at approximately $0.5 \mu \mathrm{m}$. Larger scale gravel shows a more marked broad reduction in snow reflectance in VNIR, with absorption features beginning earlier, at approximately $0.38 \mu \mathrm{m}$. Full supraglacial debris cover results in loss of characteristic snow and ice VNIR reflectance absorption features, and debris mineralogy dominates the VNIR-SWIR reflectance signature. SWIR in particular is used to differentiate mineral components, while VNIR can signal transition metal abundance. To note, minor detector related signal influences can be seen in some Fig. 3 spectra at 1.0 and $1.8 \mu \mathrm{m}$ (further discussed in Painter, 2011). Satellite reflectance from the ASTER AST_07XT data product is plotted for corresponding bare ice and full schistic debris, and exemplifies the glacier surface composition differentiation capabilities of satellite derived surface reflectance.

A detailed investigation of all gravel on snow spectra suggested that absorption features similar to sillimanite gneiss ca. $0.35-1.0 \mu \mathrm{m}$ is resolved upon fine-scale spectral inspection. Some Khumbu and Ngozumpa snow spectra displayed slight reflectance features near the organic carotinoid and chlorophyll absorption (typically 0.55 and $0.68 \mu \mathrm{m}$, respectively) (Painter et al., 2001). However, algal growth was not expected to dominate at the time of spectral measurements (Yoshimura et al., 2000), nor was visible in large quantities on either glacier. Conversely, fine debris was clearly visible and many of the snow spectra VNIR absorption features are thus attributed to mineral dust deposition, transition metalrich as confirmed by XRF results. Several minerals were identified in Ngozumpa and Khumbu supraglacial debris spectra, with dominant mineral classes identified including biotite, silicates and calcite. Moisture content of supraglacial debris was also analyzed using field spectra reflectance moisture estimation (after Liang, 2004). Supraglacial debris water content was estimated at 5\% and 15-20\% from two separate debris spectral signatures collected on the Upper Ngozumpa

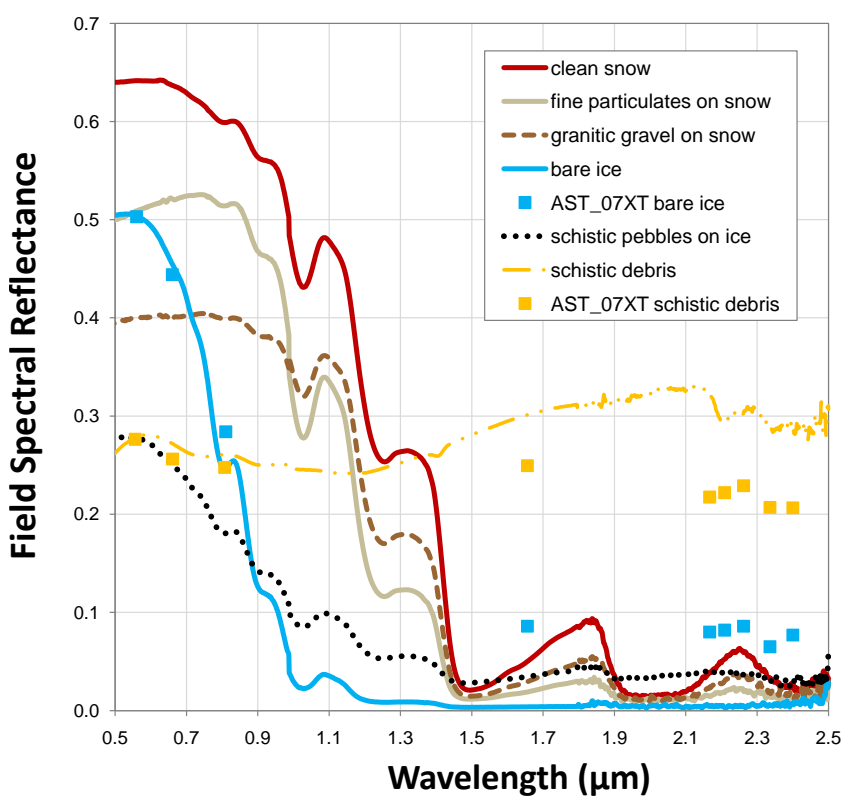

Fig. 3. Khumbu glacier snow, ice and debris field collected surface reflectance. Note the reduction in VNIR reflectance with increasing dust and debris compared to clean snow and bare ice signatures, and SWIR dominant schistic supraglacial debris signature. Satellite reflectance (ASTER AST_07XT) is compared with field reflectance for bare ice and schistic debris signatures.

glacier site (denoted UN in Fig. 2). More detailed descriptions of mineral spectra and supraglacial debris moisture results are presented in the accompanying Cryosphere Discussion paper, (Casey et al., 2011).

XRD derived supraglacial rock, gravel, soil and silt mineralogy was measured to consist primarily of quartz, feldspars, carbonates, and micas (see Table 3). Specifically, Ngozumpa glacier debris samples were largely quartz, feldspar - in the form of calcium albite, and mica - in the form of biotite, while Khumbu glacier debris samples were dominated by mica - in the form of muscovite and feldspar - in the form of calcium albite and quartz. Minor amounts of calcite were measured on both glaciers, more prevalence in Ngozumpa glacier debris samples (7 of 8 samples), compared to Khumbu glacier samples ( 2 of 14 samples). In contrast, chlorite was found to be more abundant on Khumbu glacier, with trace amounts measured in 9 of the 14 Khumbu glacier samples compared to 2 of the 8 Ngozumpa glacier samples. XRF determined silica weight percent results are displayed in Table 3 and full XRF analytical results are given in Casey et al. (2011) (snow and ice geochemical results are presented in Casey, 2012). XRF silica measurements are also compared with ASTER based silicate mapping results (Sect. 5.2). 
Table 3. In situ and satellite comparison of mineralogy and silica abundance at Ngozumpa and Khumbu glacier sample locations. XRDderived minerals are listed in order of greatest abundance per sample, along with XRF measured $\mathrm{SiO}_{2}$ weight percent and ASTER TIR estimated $\mathrm{SiO}_{2}$ weight percent. ASTER TIR $\mathrm{SiO}_{2}$ weight percent is averaged from the nearest two $90 \mathrm{~m}$ pixels to the in situ sample site.

\begin{tabular}{|c|c|c|c|c|c|}
\hline Sample ID & Site & Debris type & XRD determined mineral classes in order of abundance & $\begin{array}{l}\text { XRF derived } \\
\mathrm{SiO}_{2}\end{array}$ & $\begin{array}{l}\text { ASTER TIR } \\
\text { estimated } \mathrm{SiO}_{2}\end{array}$ \\
\hline $1 \mathrm{~N}$ & $\mathrm{UN}$ & mud & quartz, feldspar, mica, K-feldspar, calcite & 66.3 & 72.8 \\
\hline $2 \mathrm{~N}$ & $\mathrm{UN}$ & mud & quartz, feldspar, mica, K-feldspar, calcite & 66.4 & \\
\hline $3 \mathrm{~N}$ & $\mathrm{UN}$ & sand & mica, quartz, feldspar, K-feldspar, calcite & 62.7 & \\
\hline $4 \mathrm{~N}$ & $\mathrm{UN}$ & sand & quartz, mica, feldspar, K-feldspar, calcite & 65.1 & \\
\hline $5 \mathrm{~N}$ & $\mathrm{UN}$ & gravel & feldspar, quartz, K-feldspar, mica, calcite & 71.9 & \\
\hline $6 \mathrm{~N}$ & $\mathrm{UN}$ & gravel & mica, feldspar, quartz, microcline, clinochlore & 62.5 & \\
\hline $7 \mathrm{~N}$ & $\mathrm{MN}$ & rock & feldspar, feldspar, calcite, quartz, K-feldspar & 37.2 & 70.7 \\
\hline $8 \mathrm{~N}$ & $\mathrm{MN}$ & rock & calcite, wollastonite & 6.6 & \\
\hline $9 \mathrm{~K}$ & LK & mud & mica, feldspar, quartz, microcline, clinochlore & 61.4 & 77.9 \\
\hline $10 \mathrm{~K}$ & LK & mud & mica, feldspar, quartz, K-feldspar, nimite & 62.0 & \\
\hline $11 \mathrm{~K}$ & LK & rock & phlogopite, feldspar, anorthite, quartz, nimite & 63.8 & \\
\hline $12 \mathrm{~K}$ & LK & rock & feldspar, mica, phlogopite, quartz, clinochlore & 54.1 & \\
\hline $13 \mathrm{~K}$ & LK & rock & calcite, feldspar, quartz & 7.1 & \\
\hline $14 \mathrm{~K}$ & MK & sand & quartz, feldspar, microcline, mica, mica & 71.5 & 78.7 \\
\hline $15 \mathrm{~K}$ & MK & sand & feldspar, quartz, K-feldspar, mica & 71.7 & \\
\hline $16 \mathrm{~K}$ & MK & soil & feldspar, feldspar, quartz, K-feldspar, mica, illite & 71.1 & \\
\hline $17 \mathrm{~K}$ & MK & soil & feldspar, quartz, mica, K-feldspar & 68.1 & \\
\hline $18 \mathrm{~K}$ & MK & soil & mica, quartz, feldspar, K-feldspar, nimite & 69.2 & \\
\hline $19 \mathrm{~K}$ & UK & gravel & mica, quartz, feldspar, clinochlore, K-feldspar & 63.1 & 58.6 \\
\hline $20 \mathrm{~K}$ & UK & gravel & mica, quartz, feldspar, ankerite, nimite & 61.0 & \\
\hline $21 \mathrm{~K}$ & UK & sand & phlogopite, quartz, feldspar, microcline, clinochlore & 63.5 & \\
\hline $22 \mathrm{~K}$ & UK & sand & mica, feldspar, quartz, microcline, calcite, nimite & 62.8 & \\
\hline
\end{tabular}

\subsection{Optical remote sensing of supraglacial debris composition}

\subsubsection{Mineral mapping}

ASTER SWIR and TIR mineral indices provide semiquantitative estimates of mineral abundance in supraglacial debris. ASTER SWIR based layered silicate, calcite, alunite and hydroxyl-bearing mineral abundance indices are displayed in Fig. 5. For the scope of this study grayscale images of the 4 SWIR mineral indices are presented showing relative abundance of dominant surface mineralogy. Layered silicates are most abundant in Ngozumpa ablation zone supraglacial debris, calcite and hydroxyl-bearing minerals are less abundant, however, calcite and hydroxyl-bearing mineralogy displays significant variability. In contrast, the alunite index shows little contrast and low abundance over the entire region. Also displayed in Fig. 5, evidence of kinematics and pulse flow processes can be seen by the variations in layered silicate debris abundance (i.e. cyan arrows). To note, the SWIR and TIR indices can be used to further derive quantitative estimates of mineral abundances (e.g. see Ninomiya, 2004), create thematic mineral abundance maps, or apply threshold mineral abundance estimates toward further glaciologic calculations such as radiative absorption or object oriented kinematics.
Silica weight percent was derived for the Khumbu Himalaya region glaciers (Eq. 8, Fig. 6). To target mapping of supraglacial debris, a thematic silica abundance threshold of $60 \%$ was selected based on average Si abundance of regional geology. A digital elevation model was utilized to remove areas mapped at high silica content due to extreme terrain and active rock fall (i.e. slopes of 35-90 degrees). In the Khumbu Himalaya test region, this resulted in a firstorder indication of debris covered ice extent. We speculate this is due to the high supraglacial activity, mass transport, particulate deposition and sediment erosion processes on the glacier surface. These processes result in higher $\mathrm{SiO}_{2}$ weight percent on glacier as compared to surrounding non-active terrain.

Further, ASTER derived silica weight percent estimates were compared with in situ sample XRF determined $\mathrm{SiO}_{2}$ weight percent. ASTER to XRF results generally agreed (Table 3), especially in consideration of the spatial resolution variation (in situ ca. $20 \mathrm{~cm}^{2}$ point vs. $90 \mathrm{~m}^{2}$ ASTER TIR resolution), as well as the temporal resolution discrepancy of approximately $4 \mathrm{yr}$ (in situ collected 2009, ASTER data from 2005). The difference between the XRF derived $\mathrm{SiO}_{2}$ and TIR emissivity calculated $\mathrm{SiO}_{2}$ of the Ngozumpa and Khumbu glacier field measurement sites ranged from a 4.0 to 15.1 percent. In situ to satellite $\mathrm{SiO}_{2}$ results are similar to 

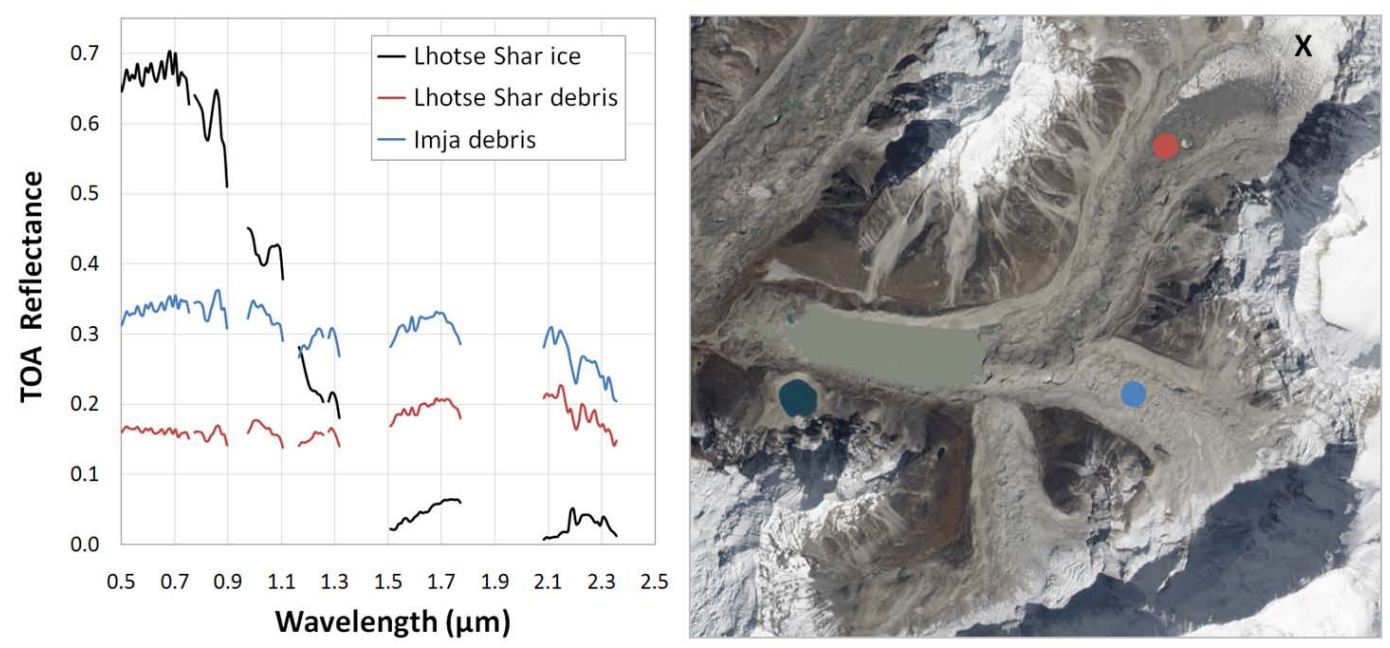

Fig. 4. Hyperion (13 May 2002) top-of-atmosphere supraglacial debris and ice reflectance plot (left) is displayed with a true color ALI (4 October 2010) $10 \mathrm{~m}$ pan-enhanced image of the Imja and Lhotse Shar glaciers. Atmospheric water vapor, oxygen and carbon dioxide absorption features were removed from the reflectance signatures. The locations of the Hyperion derived spectra for debris are indicated by the blue (Imja glacier debris) and red (Lhotse Shar glacier debris) dots and the Lhotse Shar lightly dust covered ice by the black X.
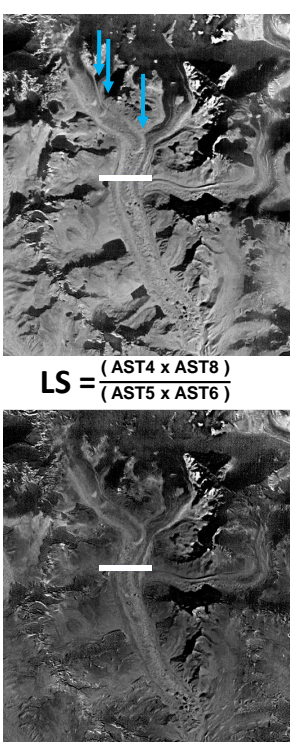

$\mathrm{OH}=\frac{(\mathrm{AST} \times \mathrm{AST7})}{\left(\mathrm{AST}^{2}\right)}$
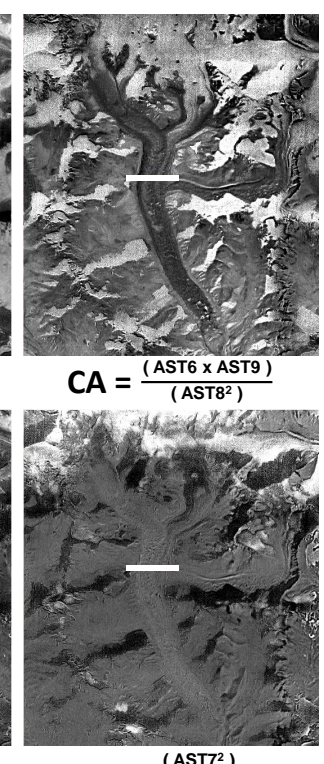

$\mathrm{AL}=\frac{\left(\mathrm{AST7}^{2}\right)}{(\mathrm{AST5} \times \mathrm{AST})}$

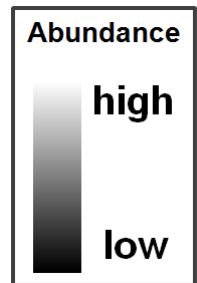

Fig. 5. ASTER SWIR radiance based mineral abundance maps of Ngozumpa supraglacial debris, clockwise from the top left, layered silicate, calcite, alunite and hydroxyl bearing. Cyan arrows on the layered silicate index point to evidence of pulse like glacial flow. The location of the transect used to investigate differing mineral abundances with respect to supraglacial temperatures in Fig. 7 are indicated by the white lines across Ngozumpa glacier.

the accuracy reported by Hook et al. (2005), who note that accuracy can be improved if the $\mathrm{SiO}_{2}$ weight percent algorithm is fine tuned to the specific region.

\subsubsection{Shortwave and thermal infrared false color composites}

We differentiated silicon dioxide rich vs. carbonate-rich Khumbu Himalayan supraglacial debris using Landsat and ASTER SWIR and TIR false color composites. Landsat ETM + SWIR band 5, 7 and TIR band 6 false color image composite from 24 January 2003 of regional glaciers is displayed in Fig. 9. Supraglacial debris composition variability is indicated by the coloring - yellow indicates silicon dioxide rich granites, while blue indicates carbonate-rich gneisses. The Khumbu glacier longitudinal schistic supraglacial debris band starting from the icefall down the center of the glacier can be visualized in blue, with granite debris bands visualized in yellow. Similar carbonate-rich vs. silicate-rich longitudinal supraglacial debris bands are visible on upper Ngozumpa glacier.

Although similar total $\mathrm{SiO}_{2}$ content was found at all six Ngozumpa and Khumbu in situ samples sites (Table 3), the more uniform spatial distribution of silicates on Ngozumpa glacier can be easily differentiated from the more distinct silicate-rich vs. carbonate-rich mineral classes found on the Khumbu glacier using the SWIR/TIR false color composite technique. False color composites can also provide an indication of mass flux. In Fig. 9, a suggestion of limited mass flux transfer at glacier confluences can be seen at the Khangri Shar, Khangri Nup and Khumbu glacier confluence (red arrows) by the distinct shifts in supraglacial mineralogy. 


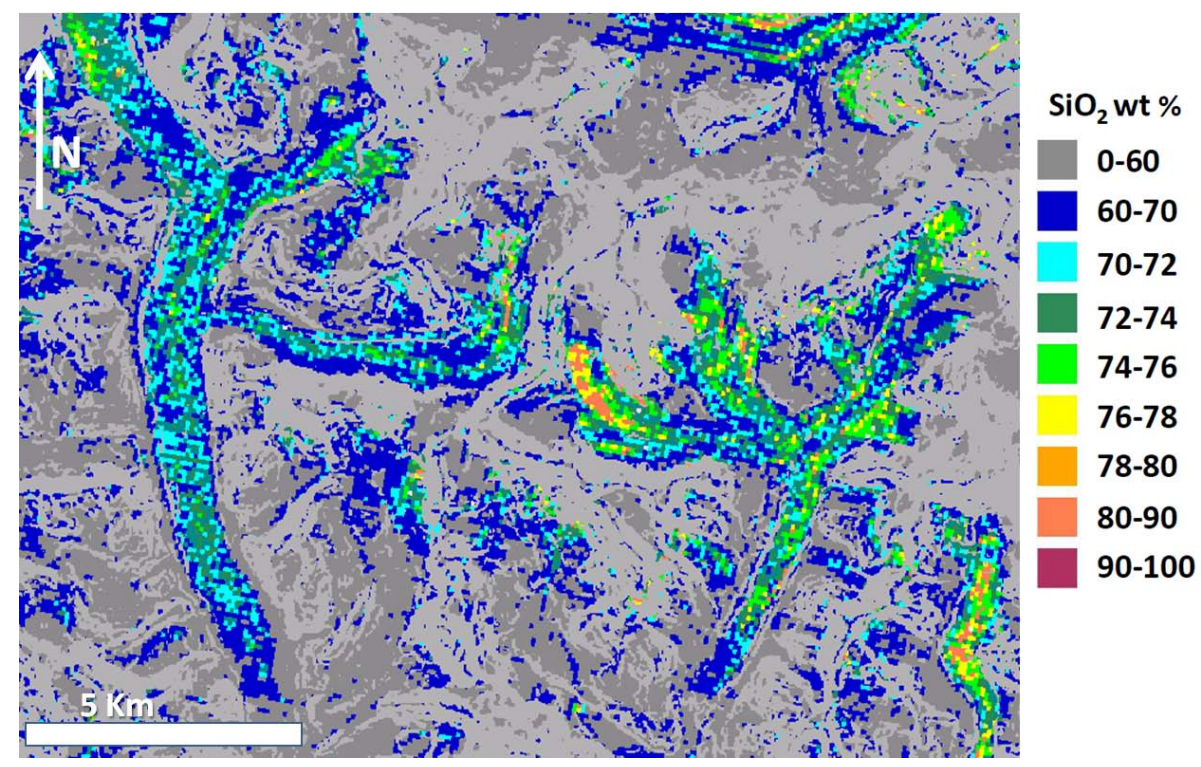

Fig. 6. Debris covered glacier areas are evident by elevated silica content in this ASTER thermal emissivity $\mathrm{SiO}_{2}$ weight percent thematic map.

\subsubsection{Hyperspectral reflectance}

Hyperion TOA reflectance spectral signatures of Imja and Lhotse Shar supraglacial debris and ice are shown in Fig. 4 along with an ALI true color $10 \mathrm{~m}$ pan enhanced true color image composite. The Hyperion reflectance plot displays the distinct granitic vs. schistic supraglacial debris types; qualitative transition metal as well as hydroxyl and carbonate absorption area differences are demonstrated at $0.4-0.8$ and 2.1-2.3 $\mu \mathrm{m}$, respectively. Hyperion analysis of ice, snow, and general mineral class qualitative differentiation was also achieved on Gyubanare and Khangri Nup glaciers from a 4 October 2010 Hyperion scene (not shown).

Limitations to Hyperion data use include relatively low signal-to-noise ratios of approximately 50:1, compared with 500:1 for airborne hyperspectral imaging (Pearlman et al., 2003; Kruse et al., 2003) and atmospheric interference. Quantitative VNIR-SWIR mineral differentiation via Hyperion requires atmospheric correction as seen in the Lhotse Shar ice planetary reflectance spectral signature with prominent atmospheric effects, despite the removal of broad water vapor, oxygen and carbon dioxide absorption features (Fig. 4). Hyperion data used in conjunction with commercial spectral and atmospheric correction software could be successful in discriminating small-scale wavelength and absorption depth-dependent characteristics of supraglacial debris (e.g. using continuum removal techniques by Clark and Lucey (1984) to determine debris components and concentrations).

\subsubsection{Glacier surface temperature}

Glacier surface temperature variation in conjunction with supraglacial debris composition changes are demonstrated in Landsat TM calculated surface temperature and calcite abundance maps in Figs. 7 and 8. Surface temperature transects display temperature variances of approximately 10 and $15^{\circ} \mathrm{C}$ with calcite mineral abundance variation on Ngozumpa and Khumbu glaciers, respectively.

In situ glacier surface temperatures measured in November and December 2009 field work sites were compared with the Landsat TM 31 October 2009 derived surface temperatures. In situ temperatures of snow, ice, and debris classes were averaged at each of the three Ngozumpa and three Khumbu glacier measurement locations. In situ temperatures of $0.4{ }^{\circ} \mathrm{C}$ for upper Khumbu, $2.4{ }^{\circ} \mathrm{C}$ for mid-Khumbu, and $6.7^{\circ} \mathrm{C}$ for lower Khumbu sample sites relate to Landsat TM 120 m pixel resolution LST's of $-3.2,4.8,3.4^{\circ} \mathrm{C}$, respectively. In consideration of the spatial and temporal resolution disparities (satellite acquisition time 10:00 a.m. with some areas in shadows vs. in situ measurement disparity $2 \mathrm{~h}$ about solar noon, also point to $120 \mathrm{~m}^{2}$ spatial disparity), general agreement was found between temperature measurements. 

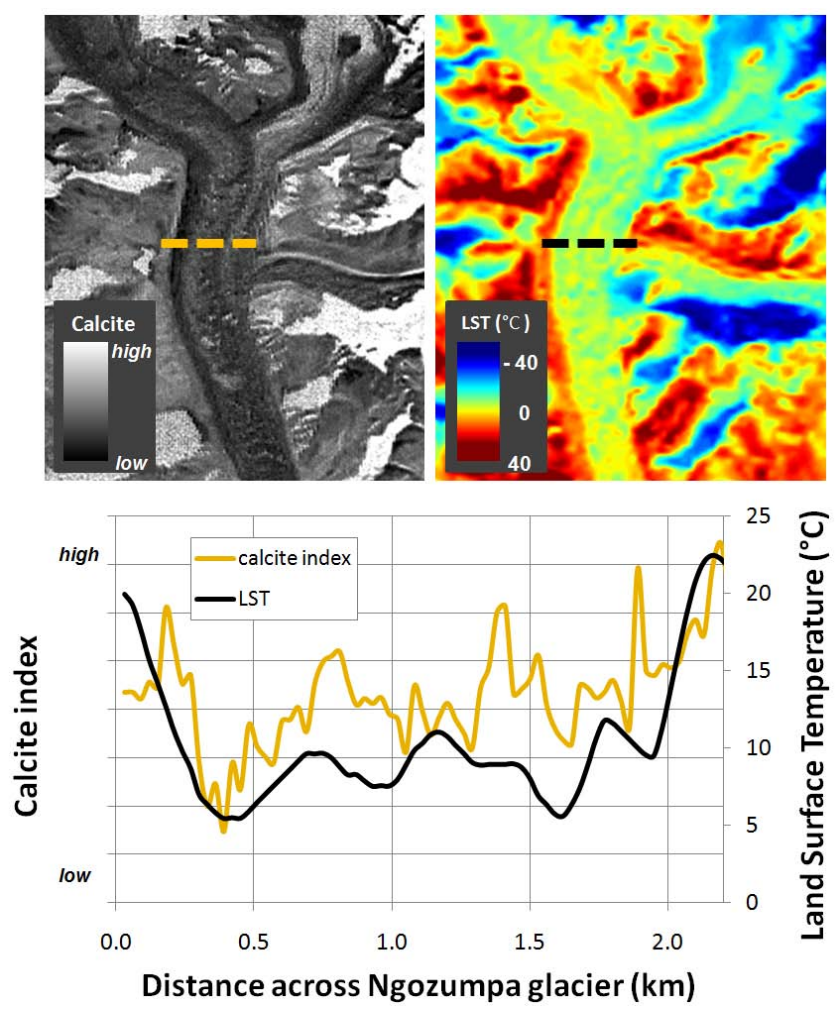

Fig. 7. Ngozumpa glacier ASTER L1B calcite abundance (top left) is compared to Landsat TM derived supraglacial temperatures (top right). The plot beneath the images displays calcite abundance vs. LST transect values across the upper Ngozumpa ablation area. Note that calcite rich areas correspond with higher glacier surface temperatures.

\subsubsection{Glacier surface velocity, streamlines}

We estimated Ngozumpa and Khumbu glacier velocities using Landsat ETM + orthorectified $15 \mathrm{~m}$ pan data from 30 October 2000 and 4 October 2002. In addition to the high spatial resolution 2000-2002 velocity estimation, we used coarser spatial resolution, but more recent Landsat TM $30 \mathrm{~m}$ near-infrared data from 5 November 2005 and 31 October 2009 to derive glacier velocities. Ngozumpa and Khumbu glacier surface velocities did not change significantly between 2000-2002 and 2005-2009 time periods. The results from the 2000-2002 velocity estimation are presented and used to derive streamlines as the higher spatial resolution allows greater accuracy. Velocity of both Ngozumpa and Khumbu glaciers is estimated at $60 \mathrm{~m} \mathrm{yr}^{-1}$ in the upper ablation zones and less than $5 \mathrm{~m} \mathrm{yr}^{-1}$ in the lower ablation zones, $\left( \pm 0.5-1\right.$ pixel; i.e. $4-7 \mathrm{~m} \mathrm{yr}^{-1}$ error) (see Fig. 9). Glacier velocity rates estimated in this study are comparable to Khumbu Himalayan glacier velocity rates derived from synthetic aperture radar (SAR) feature tracking (Luckman et al., 2007; Hambrey et al., 2008; Quincey et al., 2009) as well as optical imagery (SPOT - Seko et al. (1998);

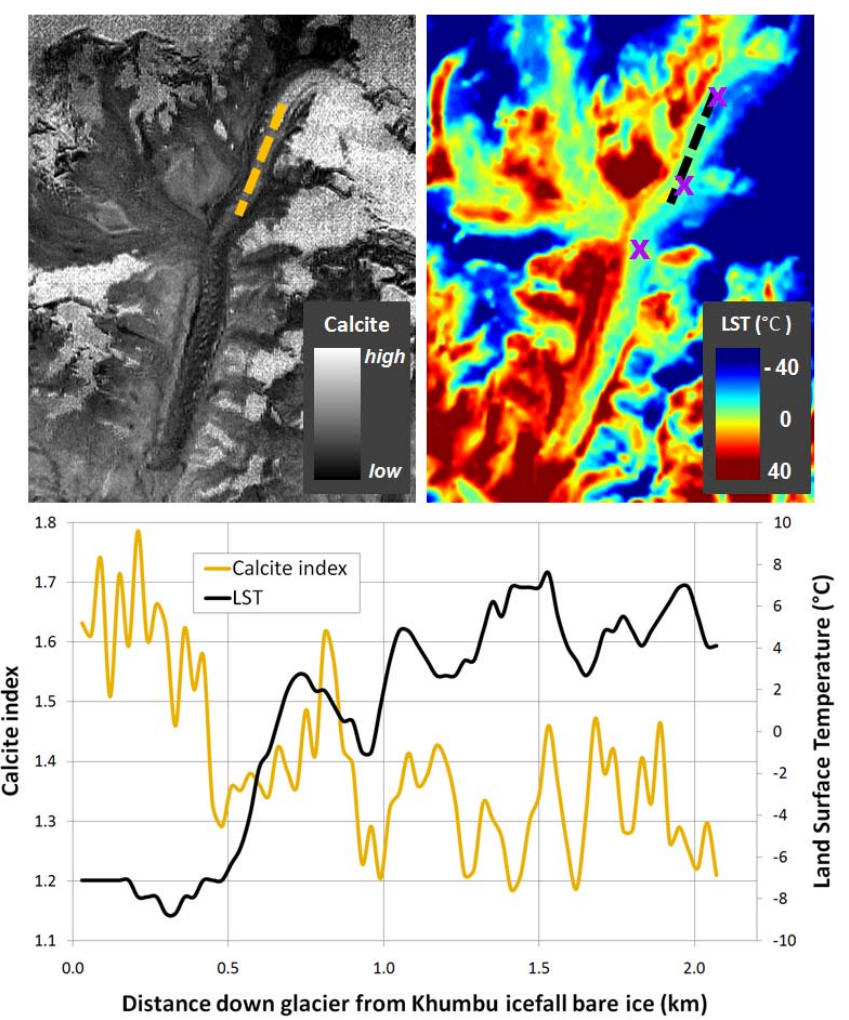

Fig. 8. Khumbu glacier ASTER L1B calcite abundance (top left) is compared with Landsat TM derived surface temperature (top right). The plot beneath displays calcite abundance and surface temperature variation down glacier. In situ surface temperature measurements are indicated on the top right map by the purple " $\mathrm{X}$ " annotations. Glacier surface temperature increases approximately $15^{\circ} \mathrm{C}$ two kilometers down glacier from the Khumbu icefall and increases further toward the terminus.

Ikonos and ASTER - Bolch et al. (2008b); and COSI-Corr (Co-registration of Optically Sensed Images and Correlation, from Leprince et al., 2007) derived ASTER - Scherler et al., 2008).

Theoretical supraglacial particulate streamlines on Ngozumpa and Khumbu glaciers indicate time scales of 380 and $450 \mathrm{yr}$, respectively (Fig. 9). Streamline interpolation stops where glacier velocities decrease below the error margin of approximately $4 \mathrm{~m} \mathrm{yr}^{-1}$. Thus, $380 \mathrm{yr}$ Ngozumpa and $450 \mathrm{yr}$ Khumbu glacier streamline estimations represent minimum glacier ablation mass transport ages. The Khumbu glacier streamline estimate from this study corresponds well with the Fushimi (1978) in situ, structural-derived estimate of Khumbu glacier ice at $410 \pm 110 \mathrm{yr}$.

\section{Synthesis}

Spectral supraglacial debris composition methods used in combination can describe glacier extent, kinematic 

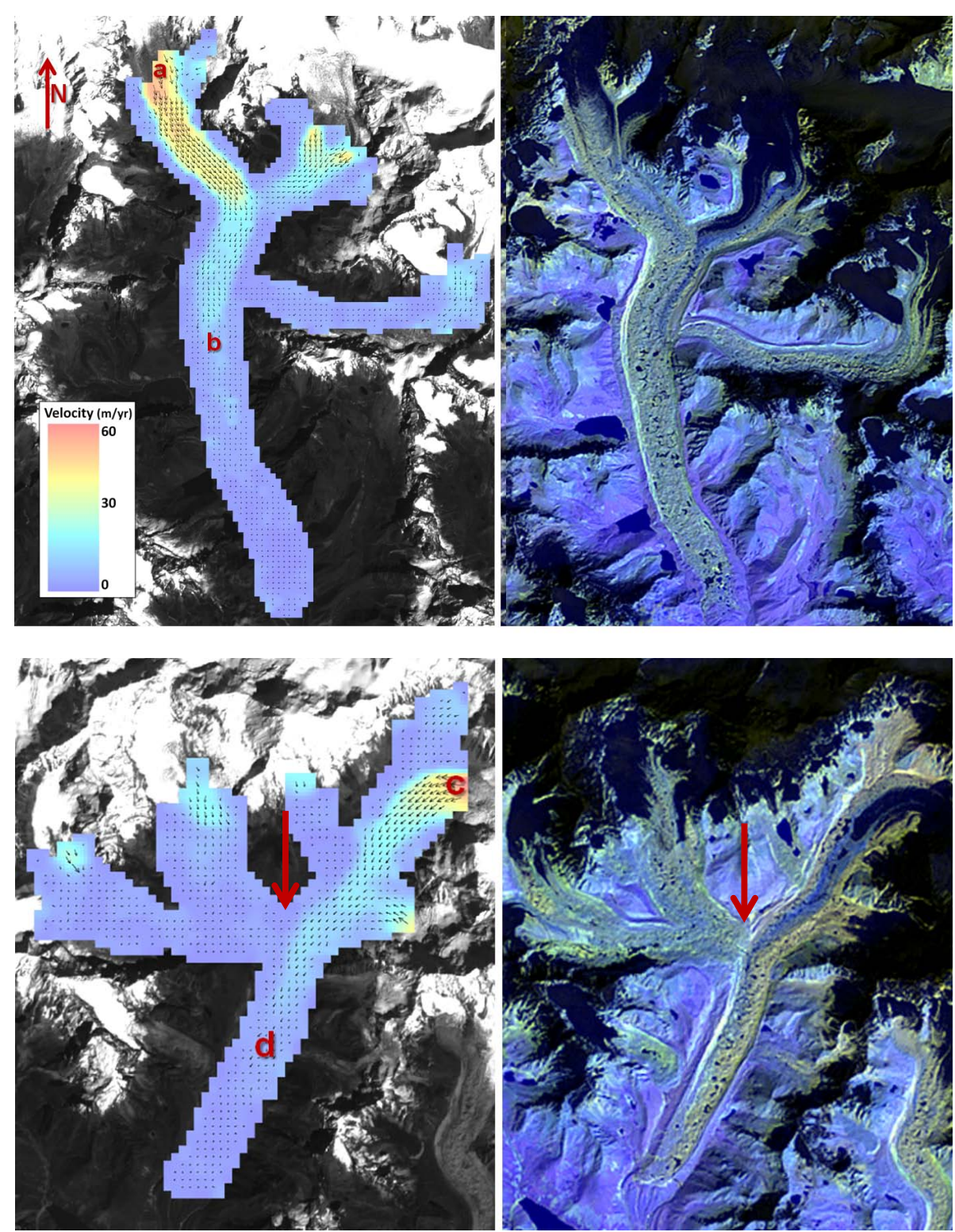

Fig. 9. Ngozumpa (upper image pair) and Khumbu (lower image pair) glacier velocity field (left) and SWIR/TIR false color composites (right) display granitic (yellow) vs. schistic (blue) supraglacial debris flux patterns. Indication of limited mass flux can be seen at the confluence of the Khangri Shar, Khangri Nup and Khumbu glacier (red arrows) by both the distinct change in supraglacial debris mineralogy as well as the low velocities mapped. Theoretical surface particulate flow from "a" to "b" on Ngozumpa glaciers and "c" to "d" on Khumbu glacier, indicate transport times of 380 and 450 years, respectively.

processes, weathering and energy balance parameters. In this section, we detail these glaciologic applications of the debris composition methods.

1. Improved satellite debris covered ice extent mapping may be achieved by using silica abundance thematic mapping, false color SWIR/TIR composites, glacier surface temperature, and/or velocity fields. Used in combination or with other mapping methods (e.g. SAR, geomorphometric approaches) the debris characteriza- tion methods may highlight debris covered ice areas at glacial boundaries that have proved challenging to detect to date.

2. Mass flux may be signaled by combining the supraglacial debris composition methods presented. Supraglacial composition can be identified via spectral reflectance signatures or false color composites. False color composites can show glacier debris sources and multidimensional (e.g. englacial) debris transport paths. 
Glacier velocity and streamlines can suggest flow paths of debris down glacier or flow processes at glacier confluences. The degree of mass flux of not only present day, but also years and decades past can be determined due to the debris patterns archived in the supraglacial debris.

3. Glacier debris activity rates, erosion and diagenesis may be analyzed via emissivity percent silica mapping, mineral indices, velocity estimations and reflectance signatures. The silica percent thematic map provides indication high silica supraglacial debris composition in areas of highest glacial velocity. Reflectance signature data can be used to confirm higher silica content of pre-weathered supraglacial debris in the upper ablation zone vs. lower silica content of more heavily weathered supraglacial debris in the lower ablation zone. Mapping of silica content of supraglacial debris may offer insight toward glacial sediment transport, erosion or areas prone to differential melt based on differing supraglacial debris composition. Theoretical particle streamline dating can also give a crude, first-order approximation of 'debris age' according to supraglacial debris type. Used with robust glaciologic sediment dating studies, such as Benn and Owen (2002); Owen et al. (2009), streamlines could roughly estimate glacier sediment dates.

4. Glacier energy balance variables in relation to supraglacial debris composition can be studied via surface temperature, mineral indices, hyperspectral reflectance derived moisture content and velocity maps. Glacier surface temperature variance depends on the amount of debris cover, surface position and composition of the debris. Spectrally estimated supraglacial moisture content could be used for calculation of debris surface albedo (Liang, 2004). Inclusion of mineral composition mapping may reduce errors in satellite glacier surface radiative absorption estimates. Further synergy of thermal and velocity data could be used to investigate climate interaction with debris covered ice, and to assess stagnation of flow toward the glacier terminus, the formation of supraglacial meltwater and subsequent glacial disintegration. Such glacier debris pattern analysis could reveal low magnitude, high repeat frequency mass events vs. episodic pattern high magnitude event, low frequency mass events - thus improving predictions of glacier mass loss.

\section{Conclusions}

Southern Himalayan glaciers are characterized by extensive debris cover and are losing significant ice mass in recent decades (e.g. Bolch et al., 2011). Sustained and widespread ice loss in the Himalayas (Berthier et al., 2007) and in other glacierized regions contributes to crustal uplift (Tamisiea et al., 2001; Larsen et al., 2005) and sea-level rise (Meier et al., 2007). Improved satellite mapping of debris covered glaciers can assist with quantification of these land ice mass changes, and thus is of paramount importance.

This study presented new methods for satellite mapping of glacier debris cover geochemistry and mineralogy, including qualitative (hyperspectral satellite TOA reflectance, SWIR/TIR false color composites) and semi-quantitative (mineral indices, emissivity estimated silica weight percent) methods. Kinematic glacial movements, including surges and confluence flow, were mapped via use of mineral indices, SWIR/TIR composites and velocity fields. Glacier surface temperature maps analyzed in conjunction with mineral composition revealed correlation between changes in mineral abundances and changes in glacier surface temperature. Satellite methods presented were tested in combination to improve description of debris covered ice areal extent, surface glacier debris mineral composition, glacier surface debris weathering and kinematics and to investigate radiative absorption of different debris types. Additionally, this study provides quantitative geochemical, mineralogic and in situ spectral data from Khumbu Himalaya glaciers not previously reported.

Continued high spectral and spatial resolution optical remote sensing is essential for debris covered glacier monitoring. ESA's forthcoming Sentinel satellites with optical sensors aimed at collecting $10 \mathrm{~m}$ spatial resolution, 5 day temporal resolution global data are promising for glacier studies. NASA's ALI, ASTER, Hyperion, Landsat and MODIS sensors offer over a decade of freely available global spectral data. This wealth of spectral satellite data has the potential to be used more broadly in supraglacial debris quantifications. Improved satellite glacier debris cover characterization will lead to reduction of uncertainties in glacier extent mapping, glaciologic thermal parameters and glacial kinematic estimations, ultimately advancing our understanding of debris covered ice ablation and ice loss.

Acknowledgements. This work was funded by the Department of Geosciences at the University of Oslo, Norway and European Space Agency's GlobGlacier project (21088/07/I-EC). We thank A. MacArthur and C. MacLellan of the Natural Environment Research Council Field Spectroscopy Facility for assistance with the field spectrometer loan (585.1210 to DIB). We also thank University of Oslo Department of Geosciences personnel R. Xie, B. L. Berg as well as M. Debella-Gilo for assistance with $\mathrm{XRD} / \mathrm{XRF}$ and velocity analysis, respectively. We are very grateful to T. Bolch and A. Racoviteanu and for detailed manuscript reviews. Special acknowledgement is due to N. S. Rai for field assistance and R. Thapa, S. Bajracharya at the International Centre for Integrated Mountain Development ICIMOD for logistic support in Kathmandu, Nepal.

Edited by: A. Klein 


\section{References}

Abrams, M. J.: The Advanced Spaceborne Thermal Emission and Reflection Radiometer (ASTER): data products for the high spatial resolution imager on NASA's Terra platform, Int. J. Remote Sens., 21, 847-859, 2000.

Abrams, M. J., Brown, D., Lepley, L., and Sadowski, R.: Remote sensing for porphyry copper deposits in southern Arizona, Economic Geology, 78, 591-604, 1983.

Adhikary, S., Nakawo, M., and Seko, K.: Dust influence on the melting process of glacier ice: experimental results from Lirung Glacier, Nepal Himalayas, chap. Debris-Covered Glaciers, 4352, 264, IAHS, 2000.

Analytical Spectral Devices, I.: FieldSpec Pro User's Guide, http: //support.asdi.com/Document/Viewer.aspx?id=19, 2002.

Atwood, D., Meyer, F., and Arendt, A.: Using L-band SAR coherence to delineate glacier extent, Can. J. Remote Sens., S186S195, 2010.

Barsi, J. A., Schott, J. R., Palluconi, F. D., and Hook, S. J.: Validation of a web-based atmospheric correction tool for single thermal band instruments, vol. 5882, SPIE, 7 pp. 2005.

Beck, R.: EO-1 User Guide v.2.3, http://edcsns17.cr.usgs.gov/eo1/ documents/EO1userguidev2pt320030715UC.pdf, 2003.

Benn, D. I. and Evans, D. J.: Glaciers and Glaciation, Hodder Education, 2010.

Benn, D. I. and Owen, L. A.: Himalayan glacial sedimentary environments: a framework for reconstructing and dating the former extent of glaciers in high mountains, Quaternary Int., 97-98, 325, 2002.

Benn, D., Wiseman, S., and Hands, K.: Growth and drainage of supraglacial lakes on the debris-mantled Ngozumpa Glacier, Khumbu Himal, Nepal, J. Glaciol., 47, 626-638, 2001.

Berthier, E., Arnaud, Y., Kumar, R., Ahmad, S., Wagnon, P., and Chevallier, P.: Remote sensing estimates of glacier mass balances in the Himachal Pradesh (Western Himalaya, India), Remote Sens. Environ., 108, 327-338, 2007.

Bhambri, R., Bolch, T., Chaujar, R., and Kulshreshtha, S.: Glacier changes in the Garhwal Himalaya, India, from 1968 to 2006 based on remote sensing, J. Glaciol., 203, 543-556, 2011.

Bishop Jr., M., J. S., and Hickman, B.: SPOT panchromatic imagery and neural networks for information extraction in a complex mountain environment, Geocarto International, 14, 19-28, 1999.

Bolch, T., Buchroithner, M. F., Kunert, A., and Kamp, U.: Automated delineation of debris-covered glaciers based on ASTER data, in: GeoInformation in Europe, Proceedings of 27th EARSeL Symposium, 403-410, 2007.

Bolch, T., Buchroithner, M., Pieczonka, T., and Kunert, A.: Planimetric and volumetric glacier changes in the Khumbu Himal, Nepal, since 1962 using Corona, Landsat TM and ASTER data, J. Glaciol., 54, 592-600, 2008a.

Bolch, T., Buchroithner, M. F., Peters, J., Baessler, M., and Bajracharya, S.: Identification of glacier motion and potentially dangerous glacial lakes in the Mt. Everest region/Nepal using spaceborne imagery, Nat. Hazards Earth Syst. Sci., 8, 13291340, 2008b.

Bolch, T., Pieczonka, T., and Benn, D. I.: Multi-decadal mass loss of glaciers in the Everest area (Nepal Himalaya) derived from stereo imagery, The Cryosphere, 5, 349-358, 2011.

Carosi, R., Lombardo, B., Musumeci, G., and Pertusati, P. C.: Ge- ology of the higher Himalayan crystallines in Khumbu Himal (Eastern Nepal), Journal of Asian Earth Sciences, 17, 785-803, 1999.

Casey, K.: Supraglacial dust and debris: geochemical compositions from glaciers in Svalbard, Norway, Nepal and New Zealand, Earth System Science Data, submitted, 2012.

Casey, K. A., Kääb, A., and Benn, D. I.: Characterization of glacier debris cover via in situ and optical remote sensing methods: a case study in the Khumbu Himalaya, Nepal, The Cryosphere Discuss., 5, 499-564, 2011.

Clark, R. N. and Lucey, P. G.: Spectral Properties of Ice-Particulate Mixtures and Implications for Remote Sensing 1. Intimate Mixtures, J. Geophys. Res., 89, 6341-6348, 1984.

Dadon, A., Ben-Dor, E., and Karnieli, A.: Use of derivative calculations and minimum noise fraction transform for detecting and correcting the spectral curvature effect (smile) in Hyperion images, IEEE T. Geosci. Remote, 48, 2603-2612, 2010.

Debella-Gilo, M. and Kääb, A.: Sub-pixel precision image matching for measuring surface displacements on mass movements using normalized cross-correlation, Remote Sens. Environ., 115, 130-142, 2011.

Fu, B., Zheng, G., Ninomiya, Y., Wang, C., and Sun, G.: Mapping hydrocarbon-induced mineralogical alteration in the northern Tien Shan using ASTER multispectral data, Terra Nova, 19, 225-231, 2007.

Fushimi, H.: Glaciations in the Khumbu Himal, Journal of the Japanese Society of Snow and Ice, Seppyo, 40, 71-77, 1978.

Fushimi, H., Yoshida, M., Watanabe, O., and Upadhyay, B.: Distributions and grain sizes of supraglacial debris in the Khumbu glacier, Khumbu Region, East Nepal, Journal of the Japanese Society of Snow and Ice, Seppyo, 42, 18-25, 1980.

Gillespie, A., Kahle, A., and Palluconi, F.: Mapping alluvial fans in Death Valley, California, using multichannel thermal infrared images, Geophys. Res. Lett., 11, 1153-1156, 1984.

Goetz, A. F. H. and Rowan, L. C.: Geologic Remote Sensing, Science, 211, 781-791, 1981.

Gupta, R. P.: Remote Sensing Geology, Springer, 2nd edn., 2003.

Hall, D. K., Chang, A. T., and Siddalingaiah, H.: Reflectances of glaciers as calculated using Landsat-5 Thematic Mapper data, Remote Sens. Environ., 25, 311-321, 1988.

Hall, D. K., Box, J. E., Casey, K. A., Hook, S. J., Shuman, C. A., and Steffen, K.: Comparison of satellite-derived and in-situ observations of ice and snow surface temperatures over Greenland, Remote Sens. Environ., 112, 3739-3749, 2008.

Hambrey, M. J., Quincey, D. J., Glasser, N. F., Reynolds, J. M., Richardson, S. J., and Clemmens, S.: Sedimentological, geomorphological and dynamic context of debris-mantled glaciers, Mount Everest (Sagarmatha) region, Nepal, Quaternary Sci. Rev., 27, 2361-2389, 2008.

Haug, T., Kääb, A., and Skvarca, P.: Monitoring ice shelf velocities from repeat MODIS and Landsat data - a method study on the Larsen C ice shelf, Antarctic Peninsula, and 10 other ice shelves around Antarctica, The Cryosphere, 4, 161-178, 2010.

Hook, S. J., Gabell, A., Green, A., and Kealy, P.: A comparison of techniques for extracting emissivity information from thermal infrared data for geologic studies, Remote Sens. Environ., 42, 123-135, 1992.

Hook, S. J., Dmochowski, J. E., Howard, K. A., Rowan, L. C., Karlstrom, K. E., and Stock, J. M.: Mapping variations in 
weight percent silica measured from multispectral thermal infrared imagery-Examples from the Hiller Mountains, Nevada, USA and Tres Virgenes-La Reforma, Baja California Sur, Mexico, Remote Sens. Environ., 95, 273-289, 2005.

Hunt, G. and Salisbury, J.: Visible and near-infrared spectra of minerals and rocks I, Silicates, Modern Geology, 1, 283-300, 1970.

Kääb, A.: Remote sensing of mountain glaciers and permafrost creep, Schriftenreihe Physische Geographie, 2005.

Kääb, A. and Vollmer, M.: Surface geometry, thickness changes and flow fields on creeping mountain permafrost: automatic extraction by digital image analysis, Permafrost and Periglacial Processes, 11, 315-326, 2000.

Kadota, T., Seko, K., Oki, T., Iwata, S., and Yamaguchi, S.: Shrinkage of the Khumbu Glacier, east Nepal from 1978 to 1995, chap. Debris-Covered Glaciers, 235-243, 264, IAHS, 2000.

Kruse, F. A.: Use of airborne imaging spectrometer data to map minerals associated with hydrothermally altered rocks in the northern grapevine mountains, Nevada, and California, Remote Sens. Environ., 24, 31-51, 1988.

Kruse, F., Boardman, J., and Huntington, J.: Comparison of airborne hyperspectral data and EO-1 Hyperion for mineral mapping, Geoscience and Remote Sensing, IEEE Transactions on, 41, 1388-1400, 2003.

Larsen, C. F., Motyka, R. J., Freymueller, J. T., Echelmeyer, K. A., and Ivins, E. R.: Rapid viscoelastic uplift in southeast Alaska caused by post-Little Ice Age glacial retreat, Earth Planet. Sci. Lett., 237, 548-560, 2005.

Leprince, S., Barbot, S., Ayoub, F., and Avouac, J.-P.: Automatic and precise orthorectification, coregistration, and subpixel correlation of satellite images, application to ground deformation measurements, IEEE T. Geosci. Remote, 45, 1529-1558, 2007.

Liang, S.: Quantitative Remote Sensing of Land Surfaces, John Wiley \& Sons, Inc., 2004.

Lougeay, R.: Detection of buried glacial and ground ice with thermal infrared remote sensing, chap. Advanced concepts and techniques in the study of snow and ice resources, 487-493, National Academy of Sciences, 1974.

Luckman, A., Quincey, D., and Bevan, S.: The potential of satellite radar interferometry and feature tracking for monitoring flow rates of Himalayan glaciers, Remote Sens. Environ., 111, 172181, Remote Sensing of the Cryosphere Special Issue, 2007.

Lyon, R. J. P.: Analysis of rocks by spectral infrared emission ( 8 to 25 microns), Economic Geology, 60, 715-736, 1965.

MacArthur, A., MacLellan, C., and Malthus, T.: The implications of non-uniformity in fields-of-view of commonly used field spectroradiometers, in: Geoscience and Remote Sensing Symposium, 2007, IGARSS 2007, IEEE International, 2890-2893, 2007.

Markham, B. and Barker, J.: Landsat MSS and TM post-calibration dynamic ranges, exoatmospheric reflectances and at-satellite temperatures, EOSAT Landsat Technical Notes, 1, 3-8, 1986.

Mather, P. M.: Computer Processing of Remotely Sensed Images, John Wiley \& Sons, Ltd., 1987.

McClure, D.: The distribution of transition metal cations in spinels, Journal of Physics and Chemistry of Solids, 3, 3-4, 1957.

Meier, M., Dyurgerov, M., Rick, U., O’Neel, S., Pfeffer, W., Anderson, R., Anderson, S., and Glazovsky, A.: Glaciers Dominate Eustatic Sea-Level Rise in the 21st Century, Science, 317, 10641067, 2007.

Mihalcea, C., Brock, B., Diolaiuti, G., D’Agata, C., Citterio, M.,
Kirkbride, M., Cutler, M., and Smiraglia, C.: Using ASTER satellite and ground-based surface temperature measurements to derive supraglacial debris cover and thickness patterns on Miage Glacier (Mont Blanc Massif, Italy), Cold Regions Science and Technology, 52, 341-354, 2008.

Miyatake, S.: Technical development report: examination of indices for discriminating rocks and minerals and their universal validity, Metal Mining Agency of Japan, 3, 1-31, 2000.

Moore, D.M. and R.C. Reynolds: X-ray diffraction and the identification and analysis of clay minerals, Oxford University Press, New York, 2nd edn., 378 pp. 1997.

Nakawo, M., Yabuki, H., and Sakai, A.: Characteristics of Khumbu Glacier, Nepal Himalaya: recent changes in the debris-covered area, Ann. Glaciol., 28, 118-122, 1999.

Nicodemus, F., Richmond, J., Hsia, J., Ginsberg, I., and Limperis, T.: Geometrical considerations and nomenclature for reflectance, Tech. rep., 1977.

Ninomiya, Y.: Rock type mapping with indices defined for multispectral thermal infrared ASTER data: case studies, in: Society of Photo-Optical Instrumentation Engineers (SPIE) Conference Series, vol. 4886, 123-132, 2003.

Ninomiya, Y.: Lithologic mapping with multispectral ASTER TIR and SWIR data, in: Society of Photo-Optical Instrumentation Engineers (SPIE) Conference Series, vol. 5234, 180-190, 2004.

Ninomiya, Y., Fu, B., and Cudahy, T. J.: Detecting lithology with Advanced Spaceborne Thermal Emission and Reflection Radiometer (ASTER) multispectral thermal infrared radiance-atsensor data, Remote Sens. Environ., 99, 127-139, 2005.

Nuimura, T., Fujita, K., Fukui, K., Asahi, K., Aryal, R., and Ageta, Y.: Temporal changes in elevation of the debris-covered ablation area of Khumbu glacier in the Nepal Himalaya since 1978, Arctic, Antarctic, and Alpine Research, 43, 246-255, 2011.

Østrem, G.: Ice melting under a thin layer of moraine, and the existence of ice cores in moraine ridges, Geografiska Annaler, 41, 228-230, 1959.

Owen, L., Robinson, R., Benn, D., Finkel, R., Davis, N., Yi, C., Putkonen, J., Li, D., and Murray, A.: Quaternary glaciation of Mount Everest, Quaternary Sci. Rev., 28, 1412-1433, 2009.

Painter, T.: Correspondence, Comment on Singh and others, "Hyperspectral analysis of snow reflectance to understand the effects of contamination and grain size”, J. Glaciol., 57, 183-185, 2011.

Painter, T. H., Duval, B., Thomas, W. H., Mendez, M., Heintzelman, S., and Dozier, J.: Detection and Quantification of Snow Algae with an Airborne Imaging Spectrometer, Appl. Environ. Microbiol., 67, 5267-5272, 2001.

Paul, F., Kääb, A., Maisch, M., Kellenberger, T., and Haeberli, W.: The new remote-sensing-derived Swiss glacier inventory. I. Methods, Ann. Glaciol., 34, 355-361, 2002.

Pearlman, J., Barry, P., Segal, C., Shepanski, J., Beiso, D., and Carman, S.: Hyperion, a space-based imaging spectrometer, IEEE T. Geosci. Remote, 41, 1160-1173, 2003.

Quincey, D., Luckman, A., and Benn, D.: Quantification of Everest region glacier velocities between 1992 and 2002, using satellite radar interferometry and feature tracking, J. Glaciol., 55, 596606, 2009.

Qunzhu, Z., Meisheng, C., Xuezhi, F., Fengxian, L., Xianzhang, C., and Wenkun, S.: A study of spectral reflection characteristics for snow, ice and water in the north of China, in: Hydrological Applications of Remote Sensing and Remote Data Transmission: 
Proceedings of the Hamburg Symposium, edited by: Goodison, B., 145, 451-462, IAHS, 1985.

Racoviteanu, A., Paul, F., Raup, B., Khalsa, S., and Armstrong, R.: Challenges and recommendations in mapping of glacier parameters from space: results of the 2008 Global Land Ice Measurements from Space (GLIMS) workshop, Boulder, Colorado, USA, Ann. Glaciol., 50, 53-69, 2010.

Rowan, L. C. and Mars, J. C.: Lithologic mapping in the Mountain Pass, California area using Advanced Spaceborne Thermal Emission and Reflection Radiometer (ASTER) data, Remote Sens. Environ., 84, 350-366, 2003.

Rowan, L. C., Kingston, M. J., and Crowley, J. K.: Spectral reflectance of carbonatites and related alkalic igneous rocks; selected samples from four North American localities, Economic Geology, 81, 857-871, 1986.

Sakai, A., Takeuchi, N., Fujita, K., and Nakawo, M.: Role of supraglacial ponds in the ablation process of a debris-covered glacier in the Nepal Himalayas, in: Debris-Covered Glaciers, 265, 119-130, IAHS, 2000.

Scherler, D., Leprince, S., and Strecker, M. R.: Glacier-surface velocities in alpine terrain from optical satellite imagery-Accuracy improvement and quality assessment, Remote Sens. Environ., 112, 3806-3819, 2008.

Scherler, D., Bookhagen, B., and Strecker, M.: Spatially variable response of Himalayan glaciers to climate change affected by debris cover, Nature Geosci., 4, 156-159, 2011.

Searle, M., Simpson, R., Law, R., Parrish, R., and Waters, D.: The structural geometry, metamorphic and magmatic evolution of the Everest massif, High Himalaya of Nepal-South Tibet, Journal of the Geological Society, 160, 345-366, 2003.

Seko, K., Yabuki, H., Nakawo, M., Sakai, A., Kadota, T., and Yamada, Y.: Changing surface features of Khumbu Glacier, Nepal Himalayas revealed by SPOT images, Bulletin of Glacier Research, 16, 33-41, 1998.

Shukla, A., Arora, M., and Gupta, R.: Synergistic approach for mapping debris-covered glaciers using optical-thermal remote sensing data with inputs from geomorphometric parameters, Remote Sens. Environ., 114, 1378-1387, 2010.

Storey, J., Scaramuzza, P., Schmidt, G., and Barsi, J.: Landsat 7 scan line corrector-off gap filled product development, in: Proceedings of Pecora 16 Global Priorities in Land Remote Sensing, American Society for Photogrammetry and Remote Sensing, 2005.
Strozzi, T., Paul, F., and Kääb, A.: Glacier mapping with ALOS PALSAR data within the ESA GlobGlacier project, in: Proceedings of the ESA Living Planet Symposium, 2010.

Suzuki, R., Fujita, K., and Ageta, Y.: Spatial distribution of thermal properties on debris-covered glaciers in the Himalayas derived from ASTER data, Bulletin of Glaciological Research, 24, 13 22, 2007.

Tamisiea, M. E., Mitrovica, J. X., Milne, G. A., and Davis, J. L.: Global geoid and sea level changes due to present-day ice mass fluctuations, J. Geophys. Res., 106, 30849-30863, 2001.

Thompson, L., Yao, T., Mosley-Thompson, E., Davis, M., Henderson, K., and Lin, P.-N.: A high-resolution millennial record of the South Asian monsoon from Himalayan ice cores, Science, 289, 1916-1919, 2000

Tucker, C. J., Grant, D. M., and Dykstra, J. D.: NASA's global orthorectified Landsat data set, Photogrammetric Engineering and Remote Sensing, 70, 313-322, 2004.

Vincent, R. and Thomson, F.: Rock-type discrimination from ratioed infrared scanner images of Pisgah Crater, California, Science, 175, 986-988, 1972.

Wang, T., Yan, G., Ren, H., and Mu, X.: Improved methods for spectral calibration of on-orbit imaging spectrometers, IEEE T. Geosci. Remote, 48, 3924-3931, 2010.

Watanabe, H. and Matsuo, K.: Rock type classification by multiband TIR of ASTER, Geosciences Journal, 7, 347-358, 2003.

Watanabe, H., Bailey, B., Duda, K., Kannari, Y., Miura, A., and Ramachandran, B.: The ASTER Data System: An Overview of the Data Products in Japan and in the United States, vol. 11, chap. 11, pp. 233-244, Springer New York, 2011.

Wessels, R., Kargel, J., and Kieffer, H.: ASTER measurement of supraglacial lakes in the Mount Everest region of the Himalaya, Ann. Glaciol., 34, 399-408, 2002.

Yoshimura, Y., Kohshima, S., Takeuchi, N., Seko, K., and Fujita, K.: Himalayan ice-core dating with snow algae, J. Glaciol., 46, 335-340, 2000. 